\title{
Mutual fund flows: an analysis of the main macroeconomic factors
}

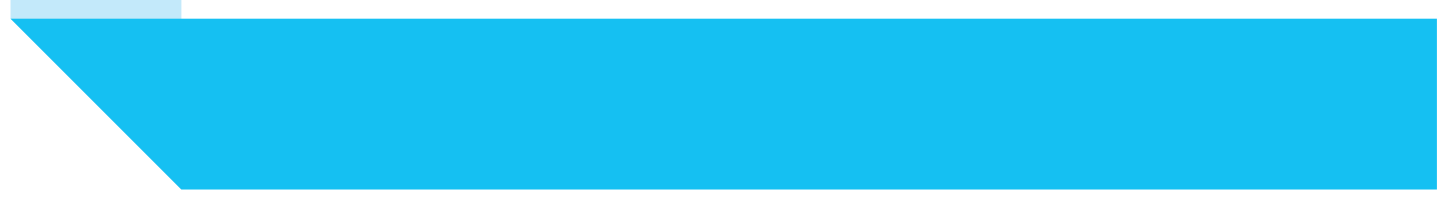

Raphael Moses Roquete (COPPEAD/UFRJ - RJ/Brasil) - raphael.moses@coppead.ufrj.br - R. Pascoal Lemme, 355, Ilha do Fundão, Rio de Janeiro-RJ, 21941-918

Otavio Henrique dos Santos Figueiredo (COPPEAD/UFRJ - RJ/Brasil) - otavio@coppead.ufrj.br Peter Fernandes Wanke (COPPEAD/UFRJ - RJ/Brasil) - peter@coppead.ufrj.br

ABSTRACT This paper analyzes whether some macroeconomic factors (country risk, IBrX volatility and Interbank Certificate of Deposit) are related to mutual fund flows for the period between January 2005 and August 2014. In order to investigate whether the flow series behaved differently during this period, the Chow test was conducted for September 2008 (the month in which the Lehman Brothers investment bank collapsed). The regressions were performed and the parameters were estimated through the OLS method for both periods, the first running from January 2005 to August 2008 and the second from September 2008 to August 2014. For the period between January 2005 and August 2008, all the variables, except for the Interbank Certificate of Deposit, proved significant, at a significance level of $10 \%$. For the subsequent period, none of the variables proved significant and the $R^{2}$ was very low, which may merely indicate that investors failed to analyze the main macroeconomic variables for mutual fund allocations or redemptions and simply considered other aspects, such as manager performance.

Keywords Investment Funds. Flow. Macroeconomic Factors.

ROQUETE, R. M.; FIGUEIREDO, 0. H. S.; WANKE, P. F. Mutual fund flows: an analysis of the main macroeconomic factors. GEPROS. Gestão da Produção, Operações e Sistemas, Bauru, Ano 10, nº 1, jan-mar/2015, p. 1-11.

D0I: 10.15675/gepros.v10i1.1221 


\section{INTRODUCTION}

The investment fund industry has been growing significantly in Brazil, particularly after the monetary stability came into effect during the 1990s, no longer being just a mechanism for shielding against inflation. Until 1994, investment funds were merely short term investment mechanisms (VARGA; WENGERT, 2011). According to Tizziani et al. (2010) this growth is grounded on the continuity of the Real Economic Reform Plan, in parallel to control of inflation and foreign debt.

Other factors also spurred this growth, such as the expansion of financial instruments on the financial market and the increasing number of managers qualified to post monetary gains. For Dalmácio (2004), investment funds allowed small investors to enter the stock market, with their money handled by specialized managers seeking the best risk $\mathrm{x}$ return ratio.

According to the Brazilian Financial and Capital Markets Association (ANBIMA, 2014), the net worth of investment funds topped R $\$ 2.5$ trillion by August 2014, compared to "only" R $\$ 400$ billion in 1996. Furthermore, Brazil's financial market has evolved in terms of regulations, offering better security to investors in general. Alterations to the regulations spurred demands for investment funds (VARGA; WENGERT, 2011). According to Calado et al. (2006), specific regulations are vital for financial market development.

Despite significant growth for this industry over the past few years, its progress has not been steady. A wide variety of factors prompt investors to allocate or assign or withdraw amounts from these funds. The purpose of this paper is to assess whether some macro-economic factors are related to fund flows (defined as the difference between allocations and redemptions). It is believed that investors also react to systematic factors rather than just fund performances. Consequently, this study adopts an approach different of other surveys that associate fund flows with manager-related factors.

This study is important, mainly from the fund manager standpoint. Although all these variables cannot be controlled, exploring their impacts paves the way for mechanisms that mitigate redemption volumes while boosting fund uptakes. This is also of interest to investors, mainly in situations with more frequent redemptions. Theoretically, the higher the redemption level, the weaker the bargaining power of the manager for some assets. In other words, the manager may be forced to abandon a specific position merely to honor its redemption commitments. For highly-leveraged funds, these impacts may be even more devastating.

According to Tizziani et al. (2010), investment allocations are also defined by investor behavior. When faced by decisions involving risk, investors will tend to adopt irrational behaviors, contradicting the theory of expected utility (KAHNEMAN; TVERSKY, 1979). Investors may weigh both gains and losses, but do not assign the same psychological value to each of them (RIBEIRO; MACHADO, 2013). Perera et al. (2009) reports that, in turbulent times, investors needing to cover their losses tend to move away from positions quickly and anxiously, without adequately processing the information, thus resulting in somewhat irrational behavior.

At times of uncertainty, the flight to quality effect is often noted, defined as capital flight from higher-risk assets to lower-risk counterparts, such as US Treasury bonds, for example (SILVA; SALLES, 2008). This effect tends to become even more marked for foreign investors that are able to shift funds to other countries. According to ANBIMA (2014), the share held by this investor segment in this industry during July 2014 hovered around $7 \%$. 
Most studies attempt to analyze the relationship between investment fund flows and factors linked directly to their managers (returns, volatility, management fees and performance). Few of them try to understand the relationships between these flows and macro-economic factors. This survey is designed to bridge this gap. The selection of mutual funds (in Portuguese: Fundos de Investimentos em Ações - FIAs) in the Brazilian fund segment was grounded on two pillars: i) investors are more eager to enter the stock market, prompted to seek out other options by the downtrend in the SELIC rate; ii) faster turnover for investment volumes, meaning that investors are more likely to allocate or redeem funds.

The explicatory variables, meaning those that will be tested as fund flow influences (or not) are: Interbank Certificate of Deposit (ICD), country risk, the volatility of IBrX Index and flow for the previous month. Consequently, the question to be answered by this survey is:

What are the determining factors for mutual fund flows in Brazil?

This survey is divided into a further four Sections. The second Section offers a review of the literature, reporting a study exploring investment fund flows. As mentioned previously, most papers relate fund flows to the performances of managers or stock indexes. The third Section addresses data collection, while the fourth Section discusses the survey method and its findings, followed by a report in the fifth Section on the main conclusions reached by this study, with suggestions for future surveys.

\section{REVIEW OF THE LITERATURE}

Between February 1998 and June 1999, Edelen and Warner (2001) addressed the relationship between the US market and 424 selected mutual funds. Using daily data, the authors found a strong positive relationship between daily returns and the market, with a one-day lag. Shrider (2009) studied possible differences in the determining factors between fund flows on bull and bear markets. They found evidence that these flows depend on market conditions, for redemptions as well as intakes. However, the author reports that during bearish periods, investors are far more concerned with absolute performance, rather than relative performance adjusted by risk. This was not noted for bullish markets, when all performance measurements were important.

Goetzmann and Massa (2003) used daily data to analyze three S\&P 500 indexed funds and their relationship to the stock market index between 1993 and 1997. The authors found evidence that investors divest their positions after the market has dropped, with a strong link between shifts in the S\&P 500 and demands for these indexed funds on the same day. The authors also analyzed a possible relationship between market volatility and fund flows, finding a positive link to net flow as well as inflows and outflows. Considering volatility as a proxy of risk, these findings are unusual.

Edwards and Zhang (1998) investigated links between fund flows and monthly returns on stocks and bonds in the US market for thirty years. Using Granger causality tests and instrumental variables, the authors concluded that these flows did not affect returns, although the reverse is also true, meaning that there is a link between returns on bonds or stocks and investment fund flows.

Sirri and Tufano (1998) conducted a study of open-ended mutual funds on the US market from December 1971 to December 1990, which was designed to relate flows to past fund performances, finding a positive relationship. However, according to these authors, investors acted asymmetrically, investing disproportionally in funds that performed very well during the previous period. Zheng (1999) explores whether it might in fact be flows that influence investment fund performances. This author analyzed 1,826 funds for more than twenty years, finding evidence that funds with higher inflows tended to perform better subsequently, although only for brief lengths of time. 
Cashman et al. (2012) analyzed US funds between April 1997 and December 2007, observing net flow, inflow and outflow separately. These authors stress that, in contrast to other studies, the period they selected encompasses bull markets (with higher inflows) as well as bear markets (with more redemptions). The authors report that net flow behave symmetrically in terms of performance, meaning that investors react similarly to good and bad performances. For inflow and outflow, the authors found an asymmetrical relationship. For inflow, investors tend to allocate more funds to better managers, rather than redeeming their less profitable investments, while for redemptions, investors tend to redeem their funds more from the worst managers rather than maintaining their allocations with the best managers.

Other authors examined whether other variables are related to investment fund flows. Luo (2003) studied the relationship between market volatility and investment fund flows in the USA between 1984 and 1998. This author divided the funds into nineteen categories, based on the investment quality of each manager. Using simple regression, the author concluded that there is a negative relationship between volatility and mutual fund flows. He found that investor reactions to volatility prompt managers to lessen their exposure during highly volatile times. Finally, the author also worked with semi-variance, noting that investors are concerned about upward and downward volatility, each of which presents a negative relationship to fund flows.

In Brazil, the study by Sanvicente (2002) is particularly noteworthy, exploring whether the performance of the São Paulo Stock Exchange Index (IBOVESPA) was crucial for net mutual fund flows in Brazil. Conducted from June 30, 1999 through to June 29, 2001 and based on daily data, this study found that the behavior of the Index up to three days earlier influenced net flow by mutual funds. The author also noted a possible link between foreign exchange rates and these flows, although not finding any statistically significant values.

According to Hersen et al. (2013), low fixed income rates prompt investors to seek more interesting alternatives. These authors feel that the stock market could respond to this need, as they noted that variable income is directly impacted by high or low interest rates. When high, investors tend to shift to fixed income options, turning to the stock market when they drop.

In their survey, these authors attempted to identify the relationship between the SELIC rate and the IBOVESPA in quantitative terms. To do so, they used a simple regression model, leading to the conclusion that for each $1 \%$ increase/reduction in the SELIC rate, the IBOVESPA rose/fell by some 1,000 points.

Medeiros and Ramos (2004) researched which variables influence the IBOVESPA through an econometric model, using as independent variables the real interest rate in Brazil, the GDP, the country risk and the S\&P500. They reached the conclusion that variables with positive effects on the IBOVESPA are economic activity, the foreign exchange rate and the S\&P500, while the interest rate and the country risk have a negative relationship with this Index. With regard to the basic interest rate for the economy, these authors said that there might be trend running counter to their findings as - with public debt clustered firmly in post-fixed options - investors might have doubts about the administration of this debt. For these authors, an upsurge in the country risk tends to reflect a lack of confidence among investors wary of the economic, political and social situation of Brazil, thus imposing constraints on foreign capital flows.

Based on the studies mentioned above, the following hypotheses were formulated:

H1: IBrX volatility negatively affects mutual fund flows.

$\mathrm{H} 2$ : Positive variations in the ICD negatively affect mutual fund flows.

H3: Higher country risk negatively affects mutual fund flows.

H4: Previous net flow positively affects mutual fund flows. 


\section{SAMPLE}

The sample examined through this survey consists of mutual fund data for the period between January 2005 and August 2014. The funds selected for this period were those classified as 'FIAs' by the Brazilian Securities Commission ${ }^{1}$ (CVM). Funds investing in units issued by other investment funds (FICs) were discarded, in order to avoid double counting of allocations and redemptions. Data on these mutual funds, the annualized daily volatility of the IBrX and the ICD were obtained from the Quantum Axis ${ }^{\circ}$ database, while country risk data were taken from the website of the Institute for Applied Economic Research ${ }^{2}$ (IPEA). It was decided to use monthly data, as most of the funds work with unit settlement at $\mathrm{D}+30$. By using with monthly data, it was felt that there was a greater likelihood of the dependent variable reflecting the effects of the independent variables in this project.

The following Table presents the development of allocations, redemptions and net flows for the period between January 2005 and August 2014.

Table 1 - Mutual Fund Flows.

\begin{tabular}{|c|c|c|c|c|c|}
\hline & Inflow (R\$) & Outflow (R\$) & Net Flow (R\$) & $\begin{array}{l}\text { Size of all Funds ( } R \$ \text { ) at } \\
\text { beginning of the year }\end{array}$ & $\begin{array}{c}\text { Annual Net } \\
\text { Flow }\end{array}$ \\
\hline 2005 & $7,870,608,342.21$ & $6,212,110,023.20$ & $1,658,498,319.01$ & $32,822,733,036.39$ & $5 \%$ \\
\hline 2006 & $16,505,267,054.47$ & $9,485,079,294.29$ & $7,020,187,760.18$ & $41,044,504,829.74$ & $17 \%$ \\
\hline 2007 & $51,771,122,985.09$ & $26,675,176,526.02$ & $25,095,946,459.07$ & $63,722,703,614.97$ & $39 \%$ \\
\hline 2008 & $46,120,843,814.20$ & $36,834,706,504.79$ & $9,286,137,309.41$ & $129,813,326,874.16$ & $7 \%$ \\
\hline 2009 & $32,145,980,733.31$ & $25,424,470,113.76$ & $6,721,510,619.55$ & $98,681,885,771.56$ & $7 \%$ \\
\hline 2010 & $43,993,687,437.25$ & $29,967,552,704.98$ & $14,026,134,732.27$ & $148,509,820,782.50$ & $9 \%$ \\
\hline 2011 & $40,164,851,456.27$ & $28,266,328,781.54$ & $11,898,522,674.73$ & $176,403,448,947.72$ & $7 \%$ \\
\hline 2012 & $69,092,943,448.36$ & $41,674,528,822.91$ & $27,418,414,625.45$ & $175,055,581,908.42$ & $16 \%$ \\
\hline 2013 & $58,145,191,427.71$ & $40,093,938,201.12$ & $18,051,253,226.59$ & $195,695,370,561.06$ & $9 \%$ \\
\hline $2014^{*}$ & $21,484,479,424.51$ & $29,099,151,396.87$ & $(7,614,671,972.36)$ & $205,556,089,708.63$ & $-4 \%$ \\
\hline
\end{tabular}

* until August 2014

Source: Author (2014).

1 Available at: http://www.cvm.gov.br/.

2 Available at: http://www.ipeadata.gov.br/ 


\section{METHODOLOGY AND FINDINGS}

In order to analyze the behavior of the monthly mutual fund flows in Brazil, it was decided to assess the relationship between the dependent variable and macro-economic variables with a one-month lag.

Monthly mutual fund flows were defined as the difference between inflow and outflow during a specific month, divided by the size of all funds at the start of the month, as shown in the following equation:

$$
\text { Flow }_{t}=\frac{\text { Inflow }_{t}-\text { Outflow }_{t}}{\text { Size }}
$$

The volatility of the IBrX was considered as a standard deviation for the daily returns during a specific month. The other explicatory variables were used in terms of the variation for the previous month.

$$
\begin{gathered}
\Delta \mathrm{ICD}_{\mathrm{t}}=\frac{\mathrm{ICD}_{\mathrm{t}}}{\mathrm{ICD}_{\mathrm{t}-1}}-1 \\
\Delta \text { Country Risk }_{\mathrm{t}}=\frac{\text { Country Risk }_{\mathrm{t}}}{\text { Country Risk }_{\mathrm{t}-1}}-1
\end{gathered}
$$

Before defining the number of lags for these variables, we observed the correlation matrix for all the lagging variables within up to 12 months. We noted a high correlation that kept pace with the rise in the number of lags, which might lead to a mistaken interpretation of the findings. Furthermore, our sample covered 116 months and an increase in the number of independent variables would remove degrees of freedom, possibly lowering the quality of the model adjustment.

Consequently, the model initially proposed may be represented as:

$$
\text { Flow }_{\mathrm{t}}=\beta_{0}+\beta_{1} \text { Flow }_{\mathrm{t}-1}+\beta_{2} \text { Vol IBrX } \mathrm{t-1}+\beta_{3} \Delta \text { Country Risk }_{\mathrm{t}-1}+\beta_{4} \Delta \mathrm{ICD}_{\mathrm{t}-1}+\varepsilon
$$

The findings shown in Table 1 suggest a structural breakdown in the flow series during 2008. The Brazilian funds segment was directly affected by the subprime crisis in 2008, with redemptions higher than intakes between September 2008 (when Lehman Brothers collapsed) and March 2009, even for the more conservative rankings (SCHIOZER; TEJERINA, 2013).

A possible structural breakdown is shown below for the period when Lehman Brothers collapsed. 
Figure 1 - Development of Monthly Mutual Fund Flows.

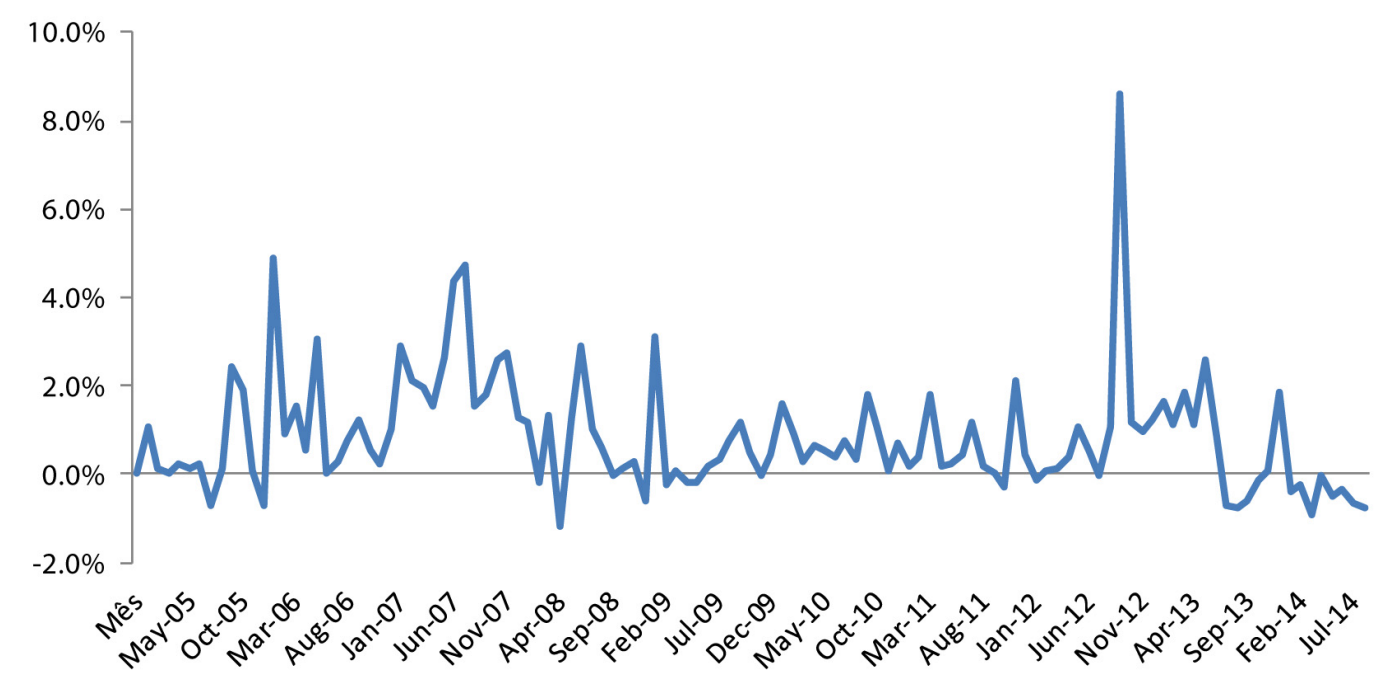

Source: Author (2014).

In order to discover whether the relationship between the variables differs at specific times, we ran the Chow test for September 2008. In this test, coefficient stability is ascertained through dividing the sample interval into two parts, and then estimating new coefficients for each sub-sample. In order to conduct this test, each sub-sample must contain more observations than the number of estimated parameters. Should there be a significant difference between the coefficients of each sub-sample, it may be considered that a structural breakdown has occurred among the model variables.

Using the EViews software for the analyzed data, H0 was rejected at a significance level of $5 \%(\mathrm{p}$-value $=0.0356)$, meaning that the null hypothesis was rejected, with statistical evidence of a structural breakdown from September 2008 onwards. The proposed model (Equation 4) should thus be checked for two periods: 1) January 2005 to August 2008 and 2) September 2008 to August 2014.

Before continuing with the proposed model, the presence of the unit root must be ascertained in the variables under consideration, checking whether any of the series are not integrated at a single order. The Dickey-Fuller test was used for the two periods under analysis: 1) January 2005 to August 2008 and 2) September 2008 to August 2014). 
Table 2 - Unit Root Test $(\mathrm{H} 0=$ Series with unit root $)$.

\begin{tabular}{|c|c|c|c|}
\hline \multicolumn{2}{|c|}{ Jan/2005 - Aug/2008 } & \multicolumn{2}{|c|}{ Sep/2008 - Aug/2014 } \\
\hline & Dickey-Fuller Test (p-value) & & Dickey-Fuller Test (p-value) \\
\hline Flow $_{\mathrm{t}}$ & $0.0003 * * *$ & Flow $_{t}$ & $0.0000 * * *$ \\
\hline Flow $_{t-1}$ & $0.0003 * * *$ & Flow $_{t-1}$ & $0.0000 * * *$ \\
\hline$\Delta \mathrm{ICD}_{\mathrm{t}-1}$ & 0.7406 & $\Delta \mathrm{ICD}_{t-1}$ & 0.3605 \\
\hline $\mathrm{d} \triangle \mathrm{ICD}_{\mathrm{t}-1}$ & $0.0000 * * *$ & $\mathrm{~d} \wedge \mathrm{ICD}_{\mathrm{t}-1}$ & $0.0001 * * *$ \\
\hline$\Delta$ Country Risk ${ }_{\mathrm{t}-1}$ & $0.0000 * * *$ & $\Delta$ Country Risk $\mathrm{t}_{\mathrm{t}-\mathrm{I}}$ & $0.0000 * * *$ \\
\hline Vol $\mathrm{IBrX}_{\mathrm{t}-1}$ & $0.0006 * * *$ & Vol IBrX $\mathrm{It}_{\mathrm{t}-1}$ & $0.0023 * * *$ \\
\hline
\end{tabular}

Notes: 1) *significant at $10 \%$, ** significant at $5 \%$ e ****significant a $1 \%$

Source: Author (2014).

Table 2 shows that the ICD series presented a unit root, thus prompting us to work with the first difference of this variable. The final model is presented in Equation 5.

$$
\text { Flow }_{\mathrm{t}}=\beta_{0}+\beta_{1} \text { Flow }_{\mathrm{t}-1}+\beta_{2} \operatorname{Vol~IBrX}_{\mathrm{t}-1}+\beta_{3} \Delta \text { Country Risk }_{\mathrm{t}-1}+\beta_{4} \mathrm{~d} \Delta \mathrm{ICD}_{\mathrm{t}-1}+\varepsilon
$$

We proceeded with the regressions and estimated the parameters for the OLS method for both periods. We noted the correlations between the variables and found no significant values in either period. We then tested the autocorrelation through the Breush-Godfrey test in EViews for both periods, and did not reject the absence of autocorrelation at 5\%, meaning that there was no need to adjust our model (Equation 5).

Finally, we tested heteroscedasticity. For the second period, the hypothesis of homoscedasticity was not rejected. However, for the period between January 2005 and August 2008, H0 was rejected, meaning that there are indications of heteroscedasticity in the series. Consequently, the coefficients were estimated for this period taking into account the correction proposed by White (1980).

The findings for the proposed model are presented below.

Table 3 - Regression Findings.

\begin{tabular}{|c|c|c|c|c|c|}
\hline \multicolumn{3}{|c|}{$\mathrm{Jan} / 2005-\mathrm{Aug} / 2008$} & \multicolumn{3}{|c|}{ Sep/2008 - Aug/2014 } \\
\hline & Estimative & $\mathrm{p}$-value & & Estimative & $\mathrm{p}$-value \\
\hline Intercept & $\begin{array}{l}2.17 \\
(0.88)\end{array}$ & $0.0177 * * *$ & Intercept & $\begin{array}{c}0.63 \\
(0.30)\end{array}$ & $0.0356 * * *$ \\
\hline Flow $_{t-1}$ & $\begin{array}{c}0.41 \\
(0.22)\end{array}$ & $0.0698 *$ & Flow $_{\mathrm{t}-1}$ & $\begin{array}{l}0.18 \\
(0.12)\end{array}$ & 0.4992 \\
\hline $\mathrm{d} \Delta \mathrm{ICD}_{\mathrm{t}-1}$ & $\begin{array}{c}0.00 \\
(0.06)\end{array}$ & 0.9833 & $\mathrm{~d} \Delta \mathrm{ICD}_{\mathrm{t}-1}$ & $\begin{array}{r}-0.03 \\
(0.03)\end{array}$ & 0.2822 \\
\hline$\Delta$ Country Risk $_{\mathrm{t}-1}$ & $\begin{array}{r}-0.03 \\
(0.02)\end{array}$ & $0.0712 *$ & $\Delta$ Country Risk $\mathrm{t}_{\mathrm{t}-1}$ & $\begin{array}{l}0.01 \\
(0.01)\end{array}$ & 0.1411 \\
\hline Vol IBrX $\mathrm{t}_{\mathrm{t}-1}$ & $\begin{array}{r}-0.06 \\
(0.03)\end{array}$ & $0.0420 * *$ & Vol IBrX $\mathrm{t}_{\mathrm{t}-1}$ & $\begin{array}{l}0.00 \\
(0.01)\end{array}$ & 0.6842 \\
\hline $\mathrm{R}^{2}$ adjusted & 0.21 & & $\mathrm{R}^{2}$ adjusted & 0.01 & \\
\hline
\end{tabular}

Notes: 1) *significant at $10 \%, * *$ significant at $5 \%$ e ***significant at $1 \%$.

2) Standard errors are shown in parentheses

Source: Author (2014). 
For the period between January 2005 and August 2008, all these variables were significant at a $10 \%$ significance level, except for the ICD. For the subsequent period, none of the variables proved significant and the $\mathrm{R}^{2}$ was very low, which may well indicate that investors failed to analyze the main macro-economic variables for mutual fund allocations or redemptions.

Possibly, the importance of manager performance or even the leverage levels established by the managers became more relevant, as some funds collapsed in 2008 due to excessive leverage. There can be no doubt that investors started to take other factors into consideration.

With regard to the hypotheses presented at the start of this study, as no variable was significant to $10 \%$ for the second period, we focused on analyzing the hypotheses for only the first period. Recapping, the hypotheses presented were:

$\mathrm{H1}$ : IBrX volatility negatively affects mutual fund flows.

$\mathrm{H} 2$ : Positive variations in the ICD negatively affect mutual fund flows.

H3: Higher country risk negatively affects mutual fund flows.

H4: Previous net flow positively affects mutual fund flows.

The first hypothesis was proven. The negative coefficient shows that higher IBrX volatility contributed negatively to mutual fund flows. Taking volatility as a proxy for investor risk, this would be expected to occur, as redemption probabilities increase in parallel to rising risks. The results converge on the conclusions reached in the studies conducted by Luo (2003) and Goetzmann and Massa (2003).

Unexpectedly, the second hypothesis was not proven. It was expected that higher profitability for bonds indexed to the ICD would attract investors to this option. This result differs from the outcome expected by Hersen et. al (2013) and the relation found by Medeiros and Ramos (2004). This may have been due to widespread confidence in the Brazilian economy between 2005 and mid-2008, with the IBrX up $133.85 \%$ during this period, compared to $64.67 \%$ for the ICD.

With regard to the third hypothesis, we found the expected sign was similar to that of Medeiros and Ramos (2004). In other words, it seemed as though higher country risk would result in redemption values outstripping allocations, particularly for foreign investors. This type of investor is normally very sensitive to variations in country risk, particularly for the emerging nations.

Finally, we also proved the fourth hypothesis, meaning that flows for the previous month positively affect those for the current month. This may indicate that investors react to past information, even with no rational justification for doing so. Consequently, for the first period we proved hypotheses 1, 3 and 4, while none of the hypothesis was supported for the second period. 


\section{FINAL REMARKS}

This study analyzed some of the main macro-economic factors that may have influenced mutual fund flows during the period between January 2005 and August 2014. The selected factors were grounded on a review of the literature, and tests were conducted to check whether all the hypotheses were significant through multiple linear regression.

The presence of a structural breakdown was noted in the series during September 2008, prompting us to test the model for two separate periods, one between January 2005 through to August 2008 and the other for September 2008 through to August 2014. For the first period, we rejected hypothesis 2 (linked to the ICD). We thus inferred that monthly mutual fund flows have a negative relationship with $\mathrm{IBrX}$ volatility and country risk, but are positive for previous month flows. However, for the second period, after the Lehman Brothers investment bank collapsed, we found no links with any variables, demonstrating that investors began to take other aspects into account for mutual fund allocations and redemptions after this macro-economic meltdown. Fund management performances and leverage levels may possibly carry more weight in investor decisions. It is also possible that, as the funds posted heavy losses during this period, investors began to monitor management attitudes more closely, in order to ensure compliance with fund regulations.

This consequently leads to the conclusion that, although mutual fund flows were affected by the macro-economic variables mentioned in this study between January 2005 and August 2008, investment fund flows are currently steered by factors other than those studied in this survey. This means that a solid understanding is required of what other factors are currently affecting fund flows, in order for fund managers and investors to protect themselves against possible future mass redemptions. An upsurge in redemptions may force the sale of assets at prices well below fair value, forcing fund unit prices down and adversely affecting the remaining investors, while also downgrading the track-records of their managers (negative aspect for publicizing funds).

This survey analyzed investor behavior towards mutual funds as a whole, not attempting to analyze differences in the ANBIMA classifications and not distinguishing the investors, nor funds of different sizes. These offer possibilities for future surveys.

\section{REFERENCES}

ANBIMA - ASSOCIAÇÃO BRASILEIRA DAS ENTIDADES DOS MERCADOS FINANCEIRO E DE CAPITAIS. Available: <http://portal.anbima.com.br/Pages/home.aspx $>$. Accessed: September 15th, 2014.

CALADO, L. R.; ROCHA, R. H.; FAMÁ, R. Auto-regulação dos serviços qualificados ao mercado de capitais. Revista GEPROS - Gestão da Produção, Operações e Sistemas, v. 2, n. 3, p. 49-57, 2006.

CASHMAN , G. D.; DELI, D. N.; NARDARI, F.; VILLUPURAM, S. Investors do respond to poor mutual fund performance: evidence from inflows and outflows. The Financial Review, v. 47, n. 4, p. 719-739, 2012.

DALMÁCIO, F. V. A teoria de agência aplicada aos fundos de investimento. Brazilian Business Review, v. 1, n. 1, p. 31-44, 2004.

EDELEN, R. M.; WARNER, J. B. Aggregate price effects of institutional trading: A study of mutual fund flow and markets returns. Journal of Financial Economics, v. 59, n. 2, p. 195-220, 2001.

EDWARDS, F.; ZHANG, X. Mutual funds and stock and bond market stability. Journal of Financial Services Research, v. 13, n. 3, p. 257-282, 1998. 
GOETZMANN, W. N.; MASSA, M. Index funds and stock market growth. The Journal of Business, v. 76, n. 1, p. 1-28, 2003.

HERSEN, A.; LIMA, F.; LIMA, J. F. Evidências empíricas da influência da taxa média de juros sobre o mercado acionário brasileiro. Gestão \& Regionalidade , v. 29, n. 85, p. 77-92, 2013.

KAHNEMAN, D.; TVERSKY, A. Prospect theory: An analysis of decision under risk. Econometrica, v. 47, n. 2, p. 263-291, 1979.

LUO, D. Market volatility and mutual fund cash flows. Yale ICF Working Paper, Working Paper no $03-21,2003$.

MEDEIROS, R. D.; RAMOS, F. C. Determinantes do desempenho e volatilidade da BOVESPA: Um estudo empírico. In: CONGRESSO DE CONTROLADORIA E CONTABILIDADE, 4, 2004, São Paulo. Anais... São Paulo: FEA/USP, 2004.

PERERA, L. C. J.; KIMURA, H.; KERR, R. B.; ISHIKAWA, S.; LIMA, F. G. Evidência de realinhamento dos mercados de ações do Brasil, França e Estados Unidos. In: COLLOQUE DE I'LFBAE, 5, 2009, Grenoble. Anais... Grenoble: [s.n.], 2009. p.1-18.

RIBEIRO, R. P.; MACHADO, M. E. R. Análise do comportamento dos investidores no Multinve\$t. Revista GEPROS - Gestão da Produção, Operações e Sistemas, n. 1, p. 107-118, 2013.

SANVICENTE, A. Z. Captação de recursos por fundos de investimento e mercado de ações. Revista de Administração de Empresas, v. 42, n. 3, p. 92-100, 2002.

SCHIOZER, R. F.; TEJERINA, D. L. A. P. Exposição a risco e captação em fundos de investimento: Os cotistas monitoram a alocação de ativos? Revista Brasileira de Finanças, v. 11, n. 4, p. 527-559, 2013.

SHRIDER, D. G. Running from a bear: How poor stock market performance affects the determinants of mutual fund flows. Journal of Business Finance \& Accounting, v. 36, n. 7/8, p. 987-1006, 2009.

SILVA,; SALLES, A. A. Uma investigação do comportamento do risco e do retorno dos fundos de investimentos brasileiros. In: ENCONTRO NACIONAL DE ENGENHARIA DE PRODUÇÃO, 28, 2008. Rio de Janeiro. Anais... Rio de Janeiro: [s.n.], 2008. p.1-11.

SIRRI, E. R.; TUFANO, P. Costly search and mutual fund flows. The Journal of Finance, v. 53, n. 5, p. 1589-1622, 1998.

TIZZIANI, E. ; KLOTZLE, M. C.; NESS JR., W. L.; NESS JR., W. L.; MOTTA, L. F. O efeito disposição na indústria brasileira de fundos de investimento em ações. Revista Brasileira de Finanças, v. 8, n. 4, p. 383-416, 2010.

VARGA, G.; WENGERT, M. A indústria de fundos de investimentos no Brasil, v. 10, n. 1, p. 66 $109,2011$.

WHITE, H. A heteroskedasticity-consistent covariance matrix estimator and a direct test for heteroskedasticity. Econometrica, v. 48, n. 4, p. 817-838, 1980.

ZHENG, L. Is money smart? A study of mutual fund investors' fund selection ability. Journal of Finance, v. 54, n. 3, p. 901-933, 1999. 
